May 2002 • NREL/CP-520-32188

\title{
Analysis of the \\ GalnP/GaAs/1-eV/Ge Cell and Related Structures for Terrestrial Concentrator Application
}

\section{Preprint}

D.J. Friedman, S.R. Kurtz, and J.F. Geisz

To be presented at the $29^{\text {th }}$ IEEE PV Specialists Conference

New Orleans, Louisiana

May 20-24, 2002

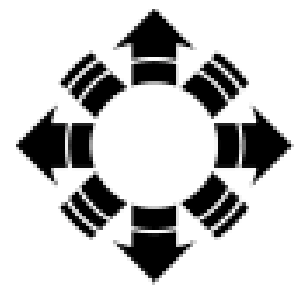

\section{NPEI}

National Renewable Energy Laboratory

1617 Cole Boulevard

Golden, Colorado 80401-3393

NREL is a U.S. Department of Energy Laboratory

Operated by Midwest Research Institute $\bullet$ Battelle $\bullet$ Bechtel

Contract No. DE-AC36-99-G010337 


\section{NOTICE}

The submitted manuscript has been offered by an employee of the Midwest Research Institute (MRI), a contractor of the US Government under Contract No. DE-AC36-99G010337. Accordingly, the US Government and MRI retain a nonexclusive royalty-free license to publish or reproduce the published form of this contribution, or allow others to do so, for US Government purposes.

This report was prepared as an account of work sponsored by an agency of the United States government. Neither the United States government nor any agency thereof, nor any of their employees, makes any warranty, express or implied, or assumes any legal liability or responsibility for the accuracy, completeness, or usefulness of any information, apparatus, product, or process disclosed, or represents that its use would not infringe privately owned rights. Reference herein to any specific commercial product, process, or service by trade name, trademark, manufacturer, or otherwise does not necessarily constitute or imply its endorsement, recommendation, or favoring by the United States government or any agency thereof. The views and opinions of authors expressed herein do not necessarily state or reflect those of the United States government or any agency thereof.

Available electronically at http://www.osti.gov/bridge

Available for a processing fee to U.S. Department of Energy and its contractors, in paper, from:

U.S. Department of Energy

Office of Scientific and Technical Information

P.O. Box 62

Oak Ridge, TN 37831-0062

phone: 865.576 .8401

fax: 865.576.5728

email: reports@adonis.osti.gov

Available for sale to the public, in paper, from:

U.S. Department of Commerce

National Technical Information Service

5285 Port Royal Road

Springfield, VA 22161

phone: 800.553 .6847

fax: 703.605.6900

email: orders@ntis.fedworld.gov

online ordering: http://www.ntis.gov/ordering.htm

Printed on paper containing at least $50 \%$ wastepaper, including $20 \%$ postconsumer waste 


\title{
ANALYSIS OF THE GalnP/GaAs/1-eV/Ge CELL AND RELATED STRUCTURES FOR TERRESTRIAL CONCENTRATOR APPLICATION
}

\author{
D.J. Friedman, Sarah R. Kurtz, and J.F. Geisz \\ National Renewable Energy Laboratory, 1617 Cole Blvd., Golden, CO 80401 USA
}

\begin{abstract}
We analyze the potential of the GalnP/GaAs/1-eV/Ge fourjunction solar cell to improve on the efficiency of the stateof-the-art GalnP/GaAs/Ge benchmark. We emphasize three factors: (1) The newly proposed terrestrial concentrator spectrum has a lower ratio of red to blue light than does the old AM1.5 direct standard spectrum. (2) Standard two-layer antireflection coatings do not provide near-zero reflectance over the full spectral range of interest for these devices. (3) GalnNAs junctions used to date for the 1-eV junction have quantum efficiencies less than $\sim 75 \%$. These factors all limit the device current, adversely affecting the four-junction efficiency. We discuss strategies for ameliorating this problem, including going to alternate structures such as a GalnP/GaAs/0.9-eV threejunction device.
\end{abstract}

\section{OBJECTIVE AND APPROACH}

There has been considerable interest in extending the GalnP/GaAs/Ge three-junction cell to higher efficiencies by the addition of a 1-eV junction between the GaAs and Ge junctions [1]. For any of the standard solar spectra, there is enough light between the GaAs and $\mathrm{Ge}$ absorption edges that the photocurrent of the threejunction structure is not limited by the photocurrent of the Ge junction in the GalnP/GaAs/Ge structure. However, when an additional $1-\mathrm{eV}$ junction is introduced, the light between the GaAs and Ge absorption edges must now be shared equally between the $\mathrm{Ge}$ and $1-\mathrm{eV}$ junctions, reducing the Ge junction photocurrent to half of that in the



Fig. 1. (a) Low-AOD and $A M 1.5 D$ direct spectra. Both spectra have been normalized to an integrated intensity of $1000 \mathrm{~W} / \mathrm{m}^{2}$. (b) Model reflectance for $\mathrm{M} \mathrm{MgF}_{2} / \mathrm{ZnS}$ coat on the multijunction structure. three-junction structure. As a result, current-limiting by the bottom two junctions in the four-junction structure is significant, with a concomitant adverse effect on the device efficiency. This paper discusses the prospects of the GalnP/GaAs/1-eV/Ge cell for terrestrial concentrator application in light of three factors that act to limit the bottom-junction currents.

(1) Recent developments in the understanding of the spectrum for concentrator operation show that a low aerosol optical depth (AOD) is appropriate for the description of representative spectral conditions [2,3]. The resulting new proposed standard direct spectrum (hereafter the "low-AOD" spectrum) has a ratio of low- to high-energy light that is lower than in the standard ASTME891 AM1.5 direct spectrum (hereafter the "AM1.5D" spectrum). The spectra are shown in Fig. 1(a). As discussed below, the limiting of the multijunction current by the third and fourth junctions is much more pronounced with the low-AOD spectrum than with the AM1.5D spectrum.

(2) Standard two-layer antireflection (AR) coatings do not provide near-zero reflectance over the full 300-1800 nm spectral range covered by these multijunction devices. Comparing the device photocurrents assuming a perfect broad-band coat to the photocurrents using a realistic twolayer coat (Fig. 1b), we show below that there is a notable difference in efficiency in going to the realistic AR coat.

(3) Unfortunately, 1-eV junctions made from the leading candidate material, GalnNAs, invariably suffer from poor minority-carrier properties in the material [4-6]. As a result, the best such junctions to date have QEs and voltages
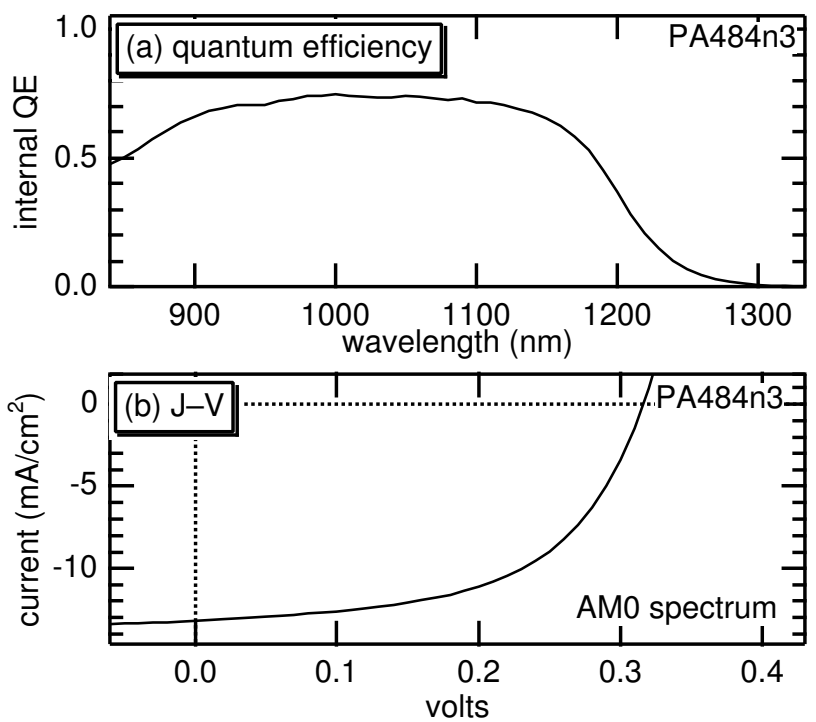

Fig. 2. (a) Internal $Q E$, and (b) J-V curve, for a representative "good" GalnNAs junction. 
significantly less than ideal. Fig. 2 shows a typical example: this device has a $Q E$ of $\sim 0.7$ and a $V_{O C} \approx 0.3 \mathrm{~V}$, far less than the $Q E=1$ and $V_{O C}=0.6 \mathrm{~V}$ expected for an ideal 1-eV junction. We will calculate the four-junction device efficiency as a function of $V_{O c}$ and $J_{S c}$ for the $1-e V$ junction, to determine how nearly ideal the junction must be to be useful in a four-junction device.

We compare the resulting four-junction device efficiency with the efficiency of the three-junction device, and find that the potential efficiency gain for the four-junction device is marginal, even with the optimistic assumption that the 1-eV junction can be made virtually ideal. When we extend this analysis to sub-ideal device performance which is characteristic of all actual GalnNAs 1-eV junctions to date, the comparison of four- to three-junction efficiency becomes even less favorable. This result leads to the consideration of alternate device structures that have the potential for improvement on the GalnP/GaAs/Ge structure by avoiding the current-limiting problems of the four-junction structure.

\section{RESULTS AND DISCUSSION}

\section{Effect of spectrum}

Table 1 compares the photocurrent available to each junction in the three-junction GalnP/GaAs/Ge ("3J\#1") structure with the four-junction structure GalnP/GaAs/1$\mathrm{eV} / \mathrm{Ge}$ ("4J"), assuming that no optical thinning of the GaAs junction is performed. The table shows that there is more than sufficient light available to the Ge junction in the 3J\#1 structure to current-match the top two junctions. However, when the 1-eV junction is introduced, the 1-eV and $\mathrm{Ge}$ junctions now have to share the light that in the 3J\#1 structure went entirely to the Ge junction. The table illustrates that not only is the $4 \mathrm{~J}$ structure current-limited by the bottom two junctions but that this current-limiting is more severe for the low-AOD spectrum than for the AM1.5D spectrum.

\section{Effect of reflection}

Conventional two-layer AR coatings such as $\mathrm{MgF}_{2} / \mathrm{ZnS}$ do

Table 1. Photocurrents $\mathrm{J}_{\mathrm{Sc} 1,2,3,4}\left(\mathrm{~mA} / \mathrm{cm}^{2}\right)$ available to each junction in various multijunnction structures, without any optical thinning of the GaAs junction. The multijunction photocurrent $\mathrm{J}_{\mathrm{SC}}$ after optical thinning is also shown. Results are shown for both zero and finite reflectance. For the $\mathrm{Ge}$ junction, an $80-\mu \mathrm{m}$ diffusion length typical of these Ge junctions is assumed [7].

\begin{tabular}{|c|c|c|c|c|c|c|c|}
\hline Device $^{(a)}$ & spectrum & reflect. & $\mathrm{J}_{\mathrm{SC} 1}$ & $\mathrm{~J}_{\mathrm{SC2}}$ & $\mathrm{J}_{\mathrm{SC} 3}$ & $\mathrm{~J}_{\mathrm{SC} 4}$ & $\mathrm{~J}_{\mathrm{SC}}$ \\
\hline 3J\#1 & AM1.5D & $\begin{array}{l}\text { none } \\
\text { finite }\end{array}$ & $\begin{array}{l}15.2 \\
14.7\end{array}$ & $\begin{array}{l}15.2 \\
14.7\end{array}$ & $\begin{array}{l}28.4 \\
26.4\end{array}$ & & $\begin{array}{l}15.2 \\
14.7\end{array}$ \\
\hline $4 \mathrm{~J}$ & AM1.5D & $\begin{array}{l}\text { none } \\
\text { finite }\end{array}$ & $\begin{array}{l}15.2 \\
14.7\end{array}$ & $\begin{array}{l}15.2 \\
14.7\end{array}$ & $\begin{array}{l}14.2 \\
13.2\end{array}$ & \begin{tabular}{|l|}
14.2 \\
13.2 \\
\end{tabular} & $\begin{array}{l}14.7 \\
14.0\end{array}$ \\
\hline 3J\#1 & low & $\begin{array}{l}\text { none } \\
\text { finite }\end{array}$ & $\begin{array}{l}15.8 \\
15.3\end{array}$ & $\begin{array}{l}15.8 \\
15.3\end{array}$ & $\begin{array}{l}26.9 \\
25.0\end{array}$ & & $\begin{array}{l}15.8 \\
15.3 \\
\end{array}$ \\
\hline $4 \mathrm{~J}$ & low & $\begin{array}{l}\text { none } \\
\text { finite }\end{array}$ & $\begin{array}{l}15.8 \\
15.3 \\
\end{array}$ & $\begin{array}{l}15.8 \\
15.3 \\
\end{array}$ & $\begin{array}{l}13.4 \\
12.5 \\
\end{array}$ & \begin{tabular}{|l|}
13.4 \\
12.5 \\
\end{tabular} & $\begin{array}{l}14.6 \\
13.9 \\
\end{array}$ \\
\hline 3J\#2 & low AOD & $\begin{array}{l}\text { none } \\
\text { finite }\end{array}$ & $\begin{array}{l}19.1 \\
18.5 \\
\end{array}$ & $\begin{array}{l}19.1 \\
18.5 \\
\end{array}$ & $\begin{array}{l}21.3 \\
19.7 \\
\end{array}$ & & $\begin{array}{l}19.1 \\
18.5\end{array}$ \\
\hline 3Ј\#3 & low AOD & $\begin{array}{l}\text { none } \\
\text { finite }\end{array}$ & $\begin{array}{l}15.8 \\
15.3 \\
\end{array}$ & $\begin{array}{l}15.8 \\
15.3 \\
\end{array}$ & $\begin{array}{l}21.1 \\
19.9 \\
\end{array}$ & & $\begin{array}{l}15.8 \\
15.3 \\
\end{array}$ \\
\hline
\end{tabular}

(a) Device descriptions:

4J: GalnP/GaAs/GalnNAs/Ge (1.85/1.42/1.0/0.7 eV)

3J\#1: GalnP/GaAs/Ge (1.85/1.42/0.7 eV)

3J\#2: GalnAsP/GalnNAs/Ge (1.78/1.23/0.7 eV)

3J\#3: GalnP/GaAs/GalnNAs (1.85/1.42/0.9 eV) not provide the desired near-zero reflectivity over the wide spectral range of interest for the three- and four-junction devices under discussion, as shown in Fig. 1(b). Table 1 shows the effect of this finite reflectance on the junction currents. For the low-AOD spectrum, the table shows that without reflectance, the $4 \mathrm{~J}$ device has $\mathrm{J}_{\mathrm{Sc}}$ (after thinning the top cells to achieve current matching) of $14.6 \mathrm{~mA} / \mathrm{cm}^{2}$, which is $92.4 \%$ of the $J_{S C}$ for device 3J\#1. With the inclusion of the finite reflectance, the $\mathrm{J}_{\mathrm{SC}}$ for the $4 \mathrm{~J}$ device decreases to $13.9 \mathrm{~mA} / \mathrm{cm}^{2}$, or $90.8 \%$ of the $\mathrm{J}_{\mathrm{SC}}$ for device 3J\#1. Thus, the finite reflectance exacerbates the currentlimiting effect in going from the $3 \mathrm{J \#} 1$ to the $4 \mathrm{~J}$ device.

It is important to emphasize that the values calculated in Table 1 for the third junction in the $4 \mathrm{~J}$ device assume an ideal 1-eV junction with a unity quantum efficiency for absorbed photons. This is a best-case scenario; in actual practice, GalnNAs cells, which are the leading candidates for the 1-eV junction, have to date not shown a QE above $\sim 0.75$. Analysis of this case will be given later. First, we consider device efficiencies assuming the best case of an ideal 1-eV junction.

\section{Efficiencies with an ideal 1-eV junction}

To know how the three- and four-junction efficiencies compare, we must determine whether adding the 1-eV junction gives a boost in voltage sufficient to more than make up for the loss in photocurrent. A state-of-the-art three-junction benchmark device has a $\mathrm{V}_{\mathrm{OC}}$ of $\sim 2.5 \mathrm{~V}$ at one-sun standard measurement conditions. Adding an ideal 1-eV junction would add about $0.6 \mathrm{~V}$ to this $\mathrm{V}_{\mathrm{OC}}$ for $\mathrm{a}$ $\sim 20 \%$ boost. We saw above that adding this junction would also lower the multijunction photocurrent by $\sim 10 \%$, assuming the low-AOD spectrum and taking reflection into account. Therefore we can conclude that adding an ideal fourth junction will give an efficiency on the order of $10 \%$ higher than the three-junction structure.

To make this estimate more precise, we calculate device efficiencies by computing the J-V curves for the three- and four-junction structures. We use a semiempirical model [8] that extrapolates the performance of the GalnP, GaAs, and $\mathrm{Ge}$ junctions from the measured performance of stateof-the-art three-junction devices $[9,10]$, while treating the GalnNAs junction by taking $\mathrm{V}_{\mathrm{OC}}$ and $\mathrm{J}_{\mathrm{SC}}$ as empirical inputs to the ideal-diode equation. (Series resistance and

Table 2. Calculated efficiencies of the GalnP/GaAs/Ge three-junction structure $3 \mathrm{J \# 1}$ under various operating conditions, and the efficiencies of the corresponding fourjunction device structure $4 \mathrm{~J}$ obtained by adding an ideal 1$\mathrm{eV}$ junction to the three-junction structure. Efficiencies for alternative three-junction structures $3 \mathrm{~J} \# 2$ and $3 \mathrm{~J} \# 3$ (as defined in Table 1) are also shown for selected operating conditions. Details of the calculation are given in Ref. [8]. spectrum suns $T(K)$ reflect. efficiency (\%)

\begin{tabular}{|c|c|c|c|c|c|c|c|}
\hline & & & & 3J\#1 & $4 \mathrm{~J}$ & 3J\#2 & 3J\#3 \\
\hline AM1.5D & 1 & 300 & $\begin{array}{l}\text { none } \\
\text { finite }\end{array}$ & $\begin{array}{l}31.8 \\
30.9\end{array}$ & $\begin{array}{l}36.4 \\
34.7\end{array}$ & & \\
\hline AM1.5D & 500 & 300 & $\begin{array}{l}\text { none } \\
\text { finite }\end{array}$ & $\begin{array}{l}38.2 \\
37.2\end{array}$ & $\begin{array}{l}44.6 \\
42.5\end{array}$ & & \\
\hline AM1.5D & 500 & 350 & $\begin{array}{l}\text { none } \\
\text { finite }\end{array}$ & $\begin{array}{l}35.5 \\
34.5\end{array}$ & $\begin{array}{l}40.6 \\
38.5\end{array}$ & & \\
\hline low-AOD & 1 & 300 & $\begin{array}{l}\text { none } \\
\text { finite }\end{array}$ & $\begin{array}{l}33.1 \\
32.1\end{array}$ & $\begin{array}{l}36.3 \\
34.5\end{array}$ & $\begin{array}{l}36.3 \\
35.0\end{array}$ & $\begin{array}{l}37.7 \\
36.6\end{array}$ \\
\hline low-AOD & 500 & 300 & $\begin{array}{l}\text { none } \\
\text { finite }\end{array}$ & $\begin{array}{l}39.8 \\
38.7\end{array}$ & $\begin{array}{l}44.4 \\
42.3 \\
\end{array}$ & $\begin{array}{l}44.4 \\
42.8 \\
\end{array}$ & $\begin{array}{l}44.5 \\
43.1 \\
\end{array}$ \\
\hline low-AOD & 500 & 350 & $\begin{array}{l}\text { none } \\
\text { finite }\end{array}$ & $\begin{array}{l}37.0 \\
35.8\end{array}$ & $\begin{array}{l}40.4 \\
38.3 \\
\end{array}$ & $\begin{array}{l}39.0 \\
37.4\end{array}$ & $\begin{array}{l}41.6 \\
40.2 \\
\end{array}$ \\
\hline
\end{tabular}


grid shadow losses are neglected here, so that the efficiencies calculated for the high-concentration operating conditions should be considered upper bounds on what is likely to be achievable in practice [8].) The results are shown in Table 2 for various concentrations and temperatures, for both the AM1.5D and low-AOD direct spectra. Raising the concentration and lowering the temperature both improve the four-junction efficiency relative to the three-junction efficiency, because the additional voltage contributed by the $1-\mathrm{eV}$ junction in the four-junction structure increases with increasing concentration and decreasing temperature.

The conditions in Table 2 that are most relevant to application in terrestrial concentrator systems are the highconcentration, elevated-temperature conditions of 500 suns and $350 \mathrm{~K}$. The table shows that using the AM1.5D spectrum and neglecting reflectance, the four-junction structure efficiency would be 5.1 efficiency points higher than the three-junction device. However, when we account for the low-AOD spectrum and the finite reflectance, the four-junction efficiency is now only 2.5 efficiency points higher than the three-junction benchmark structure.

\section{Efficiencies with a non-ideal 1-eV junction}

The estimate of 2.5 efficiency points to be gained by adding the $1-\mathrm{eV}$ junction to the three-junction structure (low AOD, 500 suns, 350K) is a best-case estimate, which assumes that the $1-\mathrm{eV}$ junction can be made essentially ideal. Unfortunately, the leading-candidate 1-eV junctions made of GalnNAs show markedly sub-ideal voltage and current. Figure 3 shows the efficiency of the four-junction structure as a function of the $\mathrm{J}_{S c}$ and $\mathrm{V}_{\mathrm{OC}}$ of the third junction for 500 suns at $T=350 \mathrm{~K}$. The low-AOD spectrum is used, and reflection is accounted for. The contour representing the $35.8 \%$ efficiency of the three-junction device (see Table 2), which the four-junction device must exceed to have any potential usefulness, is indicated in bold. The gray region illustrates (very roughly) the combinations of $\mathrm{V}_{\mathrm{OC}}$ and $\mathrm{J}_{S C}$ that are generally attained by the best 1-eV GalnNAs junctions. We see from the figure that these GalnNAs junctions would yield fourjunction efficiencies several points below breakeven with

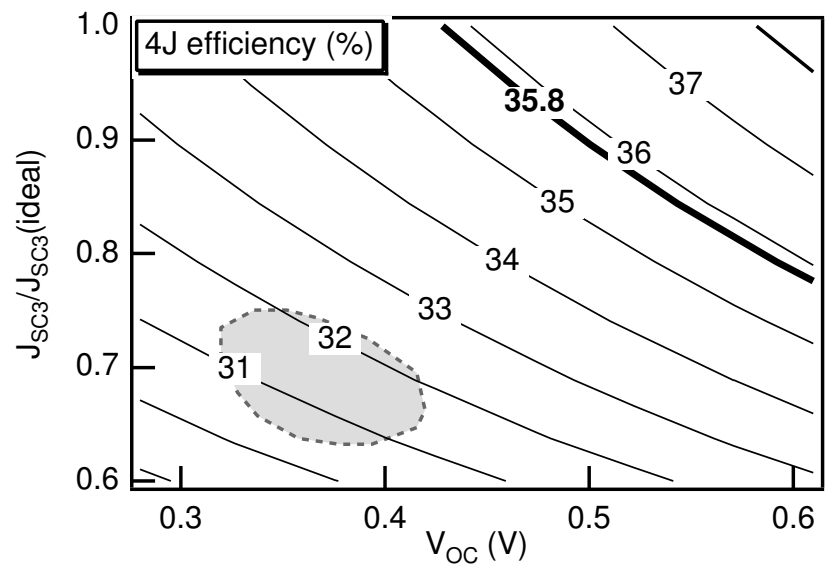

Fig. 3. Efficiency (\%) of the four-junction device as a function of the $V_{\mathrm{OC}}$ and $\mathrm{J}_{\mathrm{SC}}$ for the $1-\mathrm{eV}$ junction. The lowAOD spectrum is assumed, and reflectance is included. Operating conditions are 500 suns, $T=350 \mathrm{~K}$. $J_{S C}$ is indicated as a fraction of the $\mathrm{J}_{\mathrm{sc}}$ that would be obtained for an ideal junction that collected all absorbed photons. The grey region illustrates roughly the combinations of $V_{O C}$ and $J_{S C}$ that are generally attained by the best 1-eV GalnNAs junctions. the three-junction structure. Both $\mathrm{J}_{\mathrm{SC}}$ and $\mathrm{V}_{\mathrm{OC}}$ of the 1-eV junction must be increased significantly merely to break even; indeed, even if these parameters could be further increased to their ideal values, the four-junction structure would still exceed the three-junction breakeven by only about three efficiency points.

\section{ADDITIONAL AND ALTERNATIVE APPROACHES}

The results above show that, even if it proves possible to develop a nearly-ideal $1-e V$ device, only a few efficiency points will be gained over the three-junction benchmark device under terrestrial concentrator operating conditions. Additional improvements are desirable.

\section{Ge junction collection length}

Figure 4 shows the combined photocurrent available to the GalnP and GaAs junctions, as well as the current available to the $1-\mathrm{eV}$ and $\mathrm{Ge}$ junctions, calculated for the 4J structure as a function of the collection length in the $\mathrm{Ge}$ junction. One possibility for further improvement, suggested by Fig. 4, would be to improve the carrier collection length in the $\mathrm{Ge}$ junction. Increasing this length from $80 \mu \mathrm{m}$ to $300 \mu \mathrm{m}$ would boost the combined current of the bottom two junctions by $8 \%$, raising the efficiency by about 1.5 points. Increasing the collection in the Ge might be accomplished, at least in part, by designing reflector layers into the device to obtain multiple passes of light through the $\mathrm{Ge}$ junction. Note that the bottom two junctions (3 and 4) will always current-limit the multijunction $\mathrm{J}_{\mathrm{Sc}}$ no matter how much the Ge junction collection length is increased.



Fig. 4. Ideal junction photocurrents for the top two junctions $\left(\mathrm{J}_{\mathrm{SC}_{1}}+\mathrm{J}_{\mathrm{SC}_{2}}\right)$ and the bottom two junctions $\left(J_{S C 3}+J_{S C 4}\right)$ in the four-junction structure, as a function of the effective collection length in the Ge junction.

\section{AR coat}

Table 2 shows that four-junction device efficiencies could also be improved by as much as two efficiency points if a more sophisticated AR coat with a wider bandpass region than a conventional two-layer coat were used. This would probably necessitate the use of three- or four-layer designs for the AR coat.

\section{Alternative three-junction structures}

Finally, alternate three-junction designs may be considered that do not suffer from current-limiting by the third junction. One such approach would be a 1.75$\mathrm{eV} / 1.25-\mathrm{eV} / \mathrm{Ge}$ three-junction device. Lattice-mismatched and lattice-matched approaches to such a structure have 
been given by Dimroth [11] and by Li [12], respectively. This device structure is denoted 3J\#2 in Tables 1 and 2. Its projected efficiency, for ideal junctions, is shown in Table 2 to be very close to that of the $4 \mathrm{~J}$ structure.

Another alternative three-junction design is a GalnP/GaAs/0.9-eV three-junction structure (denoted 3J\#3 in Tables 1 and 2) in which the Ge junction is deactivated and an $0.9-\mathrm{eV}$ junction is put in its place. With a $0.9-\mathrm{eV}$ junction with a near-ideal voltage of $0.5 \mathrm{eV}$, this approach would improve the device voltage by about $0.3 \mathrm{~V}$ over the GalnP/GaAs/Ge benchmark device, without limiting the current. For the operating conditions of 500 suns, low-AOD spectrum, and $350 \mathrm{~K}$, this structure has a projected efficiency at least two efficiency points greater than any of the other device structures discussed here, and more than four points greater than the efficiency of the benchmark 3J\#1 structure. In fact, even higher efficiencies would be projected if the bottom-cell band gap were chosen to be $1.0 \mathrm{eV}$ instead of $0.9 \mathrm{eV}$. What makes the 3J\#3 structure with its $0.9 \mathrm{eV}$ bottom cell band gap especially interesting is the large excess of photocurrent available to the bottom junction compared to the photocurrent available to the top two junctions, making this device structure tolerant of the non-ideal photocurrent collection efficiencies that plague GalnNAs junctions.

Table 1 shows that under the low-AOD spectrum with finite reflectance considered, there is 19.9/15.3=1.3 times as much light available to the bottom junction as to the top two. Thus, the bottom junction need collect only $1 / 1.3=77 \%$ of the light available to it to avoid currentlimiting the top two junctions. Such a collection efficiency may be within reach for GalnNAs junctions. Figure 5 shows contours of efficiency as a function of the third junction $V_{O C}$ and $J_{S C}$ as for Fig. 3, but for this new alternative three-junction structure 3J\#3. It is hard to predict what $\mathrm{V}_{\mathrm{OC}}$ and $\mathrm{J}_{\mathrm{SC}}$ could actually be achieved for $\mathrm{a}$ $0.9-\mathrm{eV}$ GalnNAs junction, as there is a scarcity of experimental results for such a device at present. The grey region in Fig. 5 represents a (perhaps optimistic)

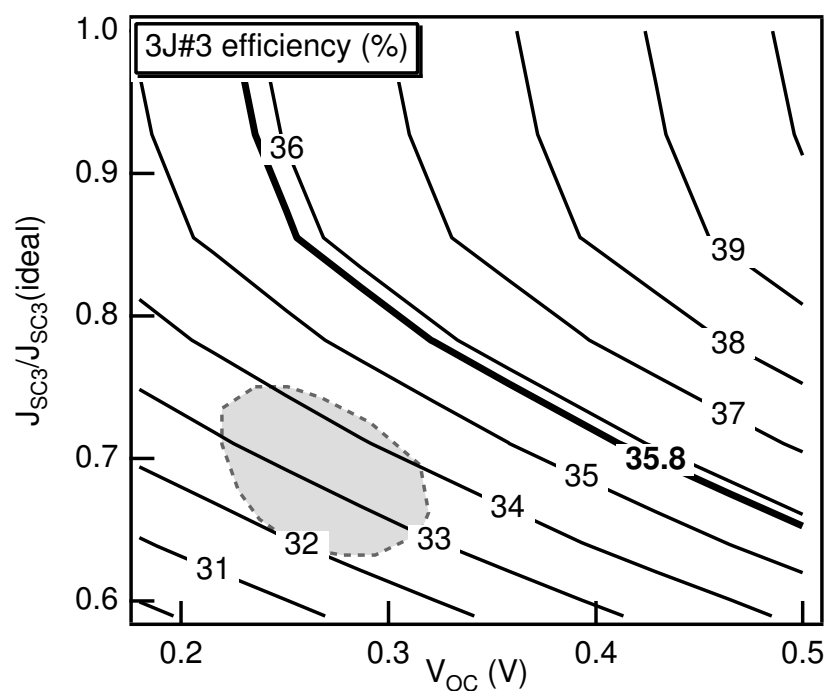

Fig. 5. Efficiency (\%) of the $3 \mathrm{J \# 3}$ device as a function of the $V_{O C}$ and $J_{S c}$ for the $0.9-e V$ third junction. Operating conditions are the same as for Fig. 3. The gray region illustrates a guess at the combinations of $V_{\rho c}$ and $J_{S C}$ that might be achievable by $0.9-\mathrm{eV}$ GalnNAs junctions (see text). guess generated by assuming that $0.9 \mathrm{eV}$ and $1.0 \mathrm{eV}$ GalnNAs junction performances would be similar except that the lower-band-gap junction would have $V_{O} s$ correspondingly lower by $0.1 \mathrm{~V}$. In the context of this assumption, a comparison of Figs. 3 and 5 indicates that we are closer to breakeven for the $3 \mathrm{J \# 3}$ structure than for the $4 \mathrm{~J}$ structure, due to the better tolerance of poor thirdjunction photocurrent collection for the 3J\#3 structure.

\section{CONCLUSIONS}

The 4J GalnP/GaAs/1-eV/Ge structure is projected to be $2.5 \%$ (absolute) more efficient than the GalnP/GaAs/Ge (3J\#1) benchmark for terrestrial concentrator operating conditions, assuming that a near-ideal $1-e V$ junction could be fabricated. To date, $1-\mathrm{eV}$ junctions have not demonstrated performance adequate for exceeding breakeven. Under terrestrial concentrator operating conditions, the GalnP/GaAs/0.9-eV structure (3J\#3) is projected to have a higher efficiency than the $4 \mathrm{~J}$ structure, and to be more tolerant of poor photocurrent collection in the $0.9 \mathrm{eV}$ junction.

\section{REFERENCES}

[1] S.R. Kurtz, D. Myers, and J.M. Olson, "Projected Performance of Three- and Four-Junction Devices using GaAs and GalnP", 26th IEEE Photovoltaic Specialists Conference, 1997, pp. 875-878.

[2] K.A. Emery, D. Myers, and S. Kurtz, "What is the appropriate reference spectrum for characterizing concentrator cells", Proceedings of the 29th Photovoltaics Specialists Conference 2002 in press,

[3] D.R. Myers et al., "Outdoor Meteorological Broadband and Spectral Conditions for Evaluating Photovoltaic Modules", 28th IEEE Photovoltaic Specialists Conference, 2000, pp. 1202.

[4] J.F. Geisz et al., "Photocurrent of $1 \mathrm{eV}$ GalnNAs lattice-matched to GaAs", J. Cryst. Growth 195, 1998, pp. 401-408.

[5] D.J. Friedman, J.F. Geisz, S.R. Kurtz, and J.M. Olson, "1-eV solar cells with GalnNAs active layer", J. Cryst. Growth 195, 1998, pp. 409-415.

[6] H.Q. Hou et al., "Novel InGaAsN pn junction for highefficiency multiple-junction solar cells", 2nd World Conf. on Photovoltaic Energy Conversion, 1998, pp. 3600-3603.

[7] D.J. Friedman and J.M. Olson, "Analysis of $\mathrm{Ge}$ junctions for GalnP/GaAs/Ge three-junction solar cells", Prog. Photovolt. 9, 2001, pp. 179-189.

[8] D.J. Friedman and S. Kurtz, "Breakeven Criteria for the GalnNAs junction in GalnP/GaAs/GalnNAs/Ge four-junction solar cells", Prog. Photovolt. 2002, pp. (in press).

[9] H.L. Cotal et al., "Triple-Junction Solar Cell Efficiencies above 32\%: The Promise and Challenges of their Application in High Concentration Ratio", 28th IEEE Photovoltaic Specialists Conference, 2000, pp. 955-960.

[10] R.R. King et al., "Next-Generation, High-Efficiency IIIV Multijunction Solar Cells", 28th IEEE Photovoltaic Specialists Conference, 2000, pp. 998-1001.

[11] F. Dimroth et al., "Metamorphic $\mathrm{Ga}_{\mathrm{y}} \mathrm{In}_{1-\mathrm{y}} \mathrm{P} / \mathrm{Ga}_{1}$ $x \ln _{x}$ As tandem solar cells for space and for terrestrial concentrator applications at C>1000 suns", Prog. Photovolt. 9, 2001, pp. 165-178.

[12] N.Y. Li et al.," "Development of $1.25 \mathrm{eV}$ InGaAsN for Triple Junction Solar Cells", 28th IEEE Photovoltaic Specialists Conference, 2000, pp. 986-989. 


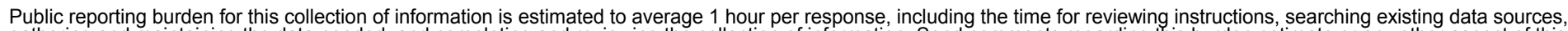


Davis Highway, Suite 1204, Arlington, VA 22202-4302, and to the Office of Management and Budget, Paperwork Reduction Project (0704-0188), Washington, DC 20503.

\begin{tabular}{|l|l|l|l|}
\hline 1. AGENCY USE ONLY (Leave blank) & $\begin{array}{l}\text { 2. REPORT DATE } \\
\text { May } 2002\end{array}$ & $\begin{array}{l}\text { 3. REPORT TYPE AND DATES COVERED } \\
29^{\text {th }} \\
\text { IEEE PVSC-Conference Paper } \\
\text { May 20-24 2002 }\end{array}$ \\
\hline
\end{tabular}

4. TITLE AND SUBTITLE

Analysis of the GalnP/GaAs/1-eV/Ge Cell and Related Structures for Terrestrial Concentrator Application: Preprint

6. $\operatorname{AUTHOR}(\mathrm{S})$

D.J. Friedman, S.R. Kurtz, and J.F. Geisz

7. PERFORMING ORGANIZATION NAME(S) AND ADDRESS(ES) National Renewable Energy Laboratory 1617 Cole Blvd.

Golden, CO 80401-3393

9. SPONSORING/MONITORING AGENCY NAME(S) AND ADDRESS(ES)

National Renewable Energy Laboratory

1617 Cole Blvd.

Golden, CO 80401-3393
5. FUNDING NUMBERS PVP24401

8. PERFORMING ORGANIZATION REPORT NUMBER

11. SUPPLEMENTARY NOTES

12a. DISTRIBUTION/AVAILABILITY STATEMENT National Technical Information Service

12b. DISTRIBUTION CODE

U.S. Department of Commerce

5285 Port Royal Road

Springfield, VA 22161

13. ABSTRACT (Maximum 200 words): This conference paper describes the analysis of the potential of $\mathrm{GalnP} / \mathrm{GaAs} / 1-\mathrm{eV} / \mathrm{Ge}$ fourjunction solar cell to improve on the efficiency of the state-of-the-art GalnP/GaAs/Ge benchmark. We emphasize three factors: (1) The newly proposed terrestrial concentrator spectrum has a lower ratio of red to blue light than does the old AM1.5 direct standard spectrum. (2) Standard two-layer antireflection coatings do not provide near-zero reflectance over the full spectral range of interest for these devices. (3) GalnNAs junctions used to date for the 1-eV junction have quantum efficiencies less than $\sim 75 \%$. These factors all limit the device current, adversely affecting the four-junction efficiency. We discuss strategies for ameliorating this problem, including going to alternate structures such as a GalnP/GaAs/0.9-eV threejunction device.

14. SUBJECT TERMS: PV: four-junction solar cell; GalnP/GaAs/1-eV/Ge; terrestrial concentrator spectrum; two-layer antireflection coatings; GalnNAs junctions; minoritycarrier; photocurrent;

15. NUMBER OF PAGES

16. PRICE CODE

17. SECURITY CLASSIFICATION OF REPORT Unclassified
18. SECURITY CLASSIFICATION OF THIS PAGE Unclassified
19. SECURITY CLASSIFICATION OF ABSTRACT Unclassified
20. LIMITATION OF ABSTRACT

UL 